1992, twenty-three people out of 3,463 were accepted across Canada for humanitarian considerations. Appeals to the Minister of Immigration have been all but useless since Mr. Valcourt took office. In the last year the Minister has accepted less than a handful of people. Mr. E. was among the many who were refused.

The recently-announced changes to the Immigration Act not only fail to address the need for a more effective safety net, they introduce the possibility that even more errors will occur. The new Act makes it necessary for some refugee claimants to convince both of the Refugee Board members hearing their case to accept them. At present only one assenting member is required, giving the refugee the benefit of the doubt. The new Act also gives expanded exclusion powers to immigration officers at initial interviews. The proposed change to the Immigration Act that allows for a complaints procedure acknowledges that there are problems with the Refugee Board members, but offers no relief to the failed refugee claimant.

To ensure that our refugee determination system meets the high standards that Mr. Valcourt talks about, there must be an appeal on the merits of a case with the possibility of entering new evidence. Canada must have a safety net to ensure that genuine refugees are not returned to the persecution from which they fled. Without this appeal we can have no confidence in the present government's commitment to provide protection for all those Convention refugees who need it. Without this appeal we have no answers for the people we know who need Canada's protection, but who are scheduled for deportation back to Iran, Sri Lanka and Kenya.

Vigil Toronto already toldMr. E. that the Minister of Immigration refused to allow him permission to stay. Yesterday we told him that the new changes to the Immigration Act do not allow for a review of his case. He just sat and cried $\square$.

\footnotetext{
Esther Ishimura is the chairperson of Vigil Toronto, a nonprofit volunteer group that advocates on behalf of refugees in need who are denied protection in Canada.
}

\title{
The Canadian Council for Refugees (CCR) Spring 1992 Session Resolutions
}

\section{Language Training}

RESOLUTION 1: The CCR to send a telegram to the Minister of Employment and Immigration requesting that implementation of the Language Instruction for Newcomers (LINC) and Labour Market Language Training (LMLT) programs be postponed until the Federal Immigration Language Training Policy is reviewed.

RESOLUTION 2: The CCR resolved to recommend to Canada Employment and Immigration that Canadian citizens be given equal access to LINC and LMLT programs.

RESOLUTION 3: The CCR to encourage Canada Employment and Immigration to make refugee claimants eligible for the LINC and LMLT programs.

RESOLUTION 4: The CCR to urge the Canada Employment and Immigration Commission (CEIC) to: 1) adopt flexible guidelines and provide funding to increase the number of hours of language instruction to meet the needs of clients; 2) adopt flexible guidelines and increase funding to provide class sizes appropriate to clients' needs.

RESOLUTION 5: The Executive Committee of the CCR to promote adopting the Manitoba model of cooperation among stakeholders in the delivery of language training; the Executive of the CCR to encourage provincial departments overseeing the welfare of refugees and immigrants to take a leadership role in this matter; the Executive of the CCR to advise the Canadian Ministers of Education Council of the importance of this process.

\section{Overseas Protection}

RESOLUTION 6: The CCR to urge the Canadian government to release remaining Iraqi assets; encourage other governments to release similarly frozen assets in their countries; use its position in the UN to ensure that sanctions against Iraq do not cut off food, medical and rebuilding supplies; monitor purchases by Canadian or UN reps to ensure that they are distributed without discrimination.

RESOLUTION 7: Levels for government-assisted refugees. The CCR to urge: 1) the Minister of Employment and Immigration to fulfill the government's commitment to select and land 13,000 governmentassisted refugees in 1992, and to allocate resources to overseas visa posts required to meet this commitment; 2) the Minister of Cultural Communities and Immigration of Québec to increase the levels of government-assisted refugees for 1992 to at least the same percentage of the Canadian total as has been set for all other immigration levels to Québec.

RESOLUTION 8: Overseas protection of urgent protection cases. The CCR to urge the Minister of Employment and Immigration to speed up private sponsorship proceedings at overseas visa posts for refugees in urgent need of resettlement; to urge visa posts to accept referrals of protection/ vulnerable cases from the United Nations High Commissioner for Refugees (UNHCR); to urge visa posts to attend to referrals of protection/ vulnerable cases by granting Minister's Permits and conducting medical and security checks in Canada. 
RESOLUTION 9: Haitian refugees. The CCR to urge Sadako Ogata, United Nations High Commissioner for Refugees, to take a strong stand towards the United States' decision to forcibly return without a hearing all Haitian boat people and to demand fair treatment for Haitian refugees. The CCR to urge the Canadian government to support the UNHCR's position, to protest to the U.S. government, to assist in convening an international conference on the U.S. interdiction of Haitian refugees, to offer protection to those Haitian refugees whom the U.S. is unwilling to protect, to call on the international community to protect Haitian refugees.

\section{Protection of Refugees in Canada}

RESOLUTION 10: Safe third country. The CCR to ask the Parliament of Canada not to authorize the Canadian government to enter into any refugee determination allocation agreements unless they meet certain criteria.

RESOLUTION 11: Appointment of members of the Convention Refugee Determination Division (CRDD). The CCR to demand an open and systematic appointment process to the CRDD that considers qualifications and relevant experience in human rights and refugee matters; any nominee for appointment to the CRDD or for continuation as a member of the CRDD be approved in consultation with a regional Canadian Bar Association (CBA) Immigration Subsection and a regional affiliate of the CCR before being considered for appointment.

RESOLUTION 12: Change of circumstances. The CCR to present instances of inappropriate use of changed circumstances as a rationale for refusal to Employment and Immigration and to the CCRD; to recommend appropriate procedures to the CEIC and CRDD for dealing with changing circumstances; to request that UNHCR communicate to CEIC and CRDD the facts about change in circumstances; to request that the Refugee Documentation Centre make all materials equally available to claimants, lawyers, refugee hearing officers and Immigration Refugee Board (IRB) members, and that relevant country material from human rights organizations in the country of origin be translated and made part of the documentation; to ask the Refugee Documentation Centre to respond equally to all parties.

RESOLUTION 13: Policy on deportations. The CCR to endorse a policy on deportations.

RESOLUTION 14: Legal aid cuts. The CCR reaffirms the principle that refugee claimants should have competent counsel of their choice in every province and territory; that the CCR opposes any cutback in legal aid services to refugee claimants; that the CCR Executive write to the Attorneys General of British Columbia, Québec and Ontario to ensure that refugee claimants are well-represented at hearings and appeals.

\section{RESOLUTION 15: Family} reunification. The CCR Executive to set up a task force or design another strategy for consolidating all family reunification issues towards an effective policy change.

\section{Refugee Women's Issues}

RESOLUTION 16: Women at risk. The CCR to request that: 1) the Ministry of Employment and Immigration increase the number of women accepted to reflect the needs identifed by the UNHCR and others; 2) the Ministergive the program priority and speed up the processing for arrival in Canada within three months of submission of application; 3 ) the Minister put a mechanism in place to provide ongoing monitoring to ensure that program goals are being met.

RESOLUTION 17: Independence of women in the refugee claim process. The CCR to communicate with the Minister of Employment and Immigration to request that: 1) women be informed of their right to make a refugee claim independent of their spouses; 2) in cases of marriage breakdown, where women's claims are dependent on their spouses, the women be permitted to make independent refugee claims immediately.

RESOLUTION 18: Cultural sensitivity of Canadian officials. The CCR to communicate with the Minister of Employment and Immigration, the Governor in Council, the Immigration and Refugee Board (IRB) and the appropriate lawyers' associations requesting that: 1) resource people from refugee-producing countries and NGOs be recruited to provide gender and cultural sensitivity training to staff; 2) more women be hired as IRB members, overseas visa officers and interpreters; 3) refugee women be given the opportunity to be interviewed in sensitive matters by women employees of the Ministry, IRB members and interpreters; 4) adequate procedures for hearings of women refugee claimants be implemented; 5) training for IRB members and employees on this issue be mandatory; 6) similar training be organized for appropriate lawyers' organizations or associations.

RESOLUTION 19: Women in detention centres. The CCR to communicate with the Government of Canada requesting that a national body be established to monitor detention centres to ensure that: 1) needs of women with children be addressed to prevent splitting of families; 2) women be separated from men to whom they are not related either legally or by common law; 3 ) people be placed under the observation of guards of their own 
gender; 4) reasonable bail conditions be set so they can be bailed out.

RESOLUTION 20: CCR settlement mandate. The CCR settlement mandate to be discussed by the $\mathrm{CCR}$ Executive, the Settlement Core Group and the strategic planning committee, coordinated by the president, the chairpersons of the working groups and CCR staff; the role of settlement within the mandate of the CCR be refined and clarified through a discussion paper to be distributed prior to the November 1992 AGM; a revitalized mission statement to include recommendations from the discussion paper regarding an expanded mandate to address the needs of settlement agencies.

RESOLUTION 21: Fingerprinting. The CCR to oppose any Canadian law or policy that results in fingerprinting refugee claimants without reasonable or probable cause that they may have committed a criminal offence; the CCR to call on the Government of Canada not to introduce into Parliament any changes in legislation that would allow fingerprinting of refugee claimants without reasonable or probable cause that they may have committed a criminal offence.

RESOLUTION 22: UNHCR. The CCR to call on the UNHCR to fulfil its obligations to protect refugees and not to allow its work to be used to support an increasingly restrictive approach to refugee definition in Canada; the $C C R$ to ask the UNHCR to urge the Canadian government for a mechanism to review errors and to listen to nongovernmental organizations, such as Vigil and Amnesty International; the CCR to urge the UNHCR in Geneva to review the actions of UNHCR in Canada with regard to position papers on countries that are being used by the IRB to refuse real refugees.

RESOLUTION 23: Refugee
participation policy.
RESOLUTION 24: Safety nets for refugees. The CCR to call on the Canadian government to: introduce legislation to allow for the reopening of refugee claims when there is a change of circumstances, new evidence, evidence not previously available or in cases where the claimant would suffer a serious injustice if the claim is not reopened; ensure that the humanitarian and compassionate review process allow for correction of errors at the CRDD hearing and admission of new evidence, and examine whether the claimant would be in danger, notwithstanding that the claimant has already appeared before the CRDD; establish joint regional advisory committees composed of delegates of the Minister, immigration lawyers and refugee advocates to review negative decisions in a post-claim review process; establish an appeal system for reviewing negative decisions; introduce an amendment to the current leave requirements to the federal court to include as of right an oral application and to require the court to give reasons for refusing leave. The CCR Executive and member agencies to publicize the need for the above measures and pressure the government to enact these measures. The CCR to call on the IRB not to assign any claims to members who have demonstrated bias. ‥

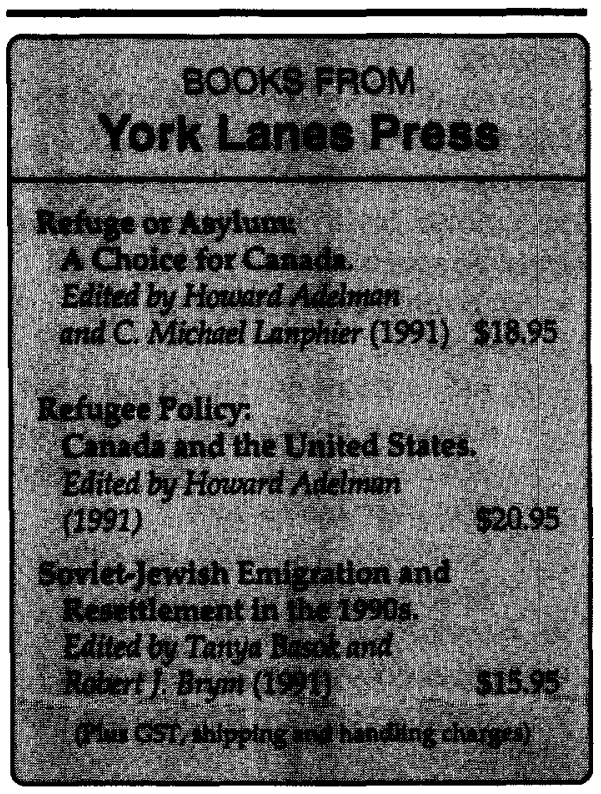

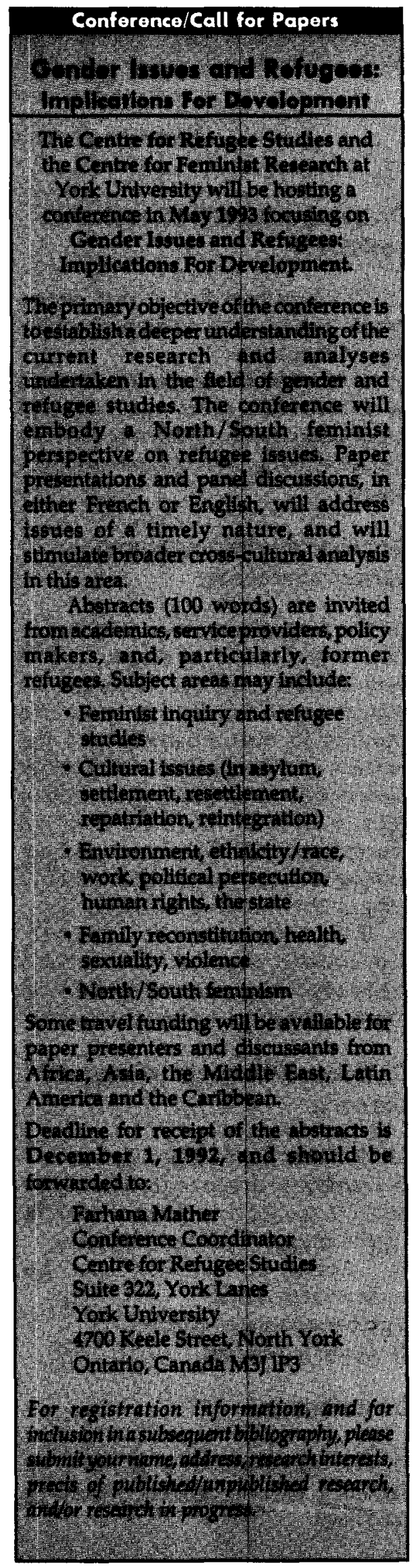

